\title{
Synthetic studies towards the anti-inflammatory agent, oleocanthal using a Johnson-Claisen (orthoester) rearrangement strategy
}

\author{
Jui Thiang Brian Kueh, ${ }^{a}$ Patrick D. O'Connor, ${ }^{\text {a }}$ Helmut Hügel ${ }^{\text {, }}$, and \\ Margaret A. Brimble ${ }^{\mathrm{a} *}$ \\ ${ }^{a}$ Department of Chemistry, University of Auckland, Private Bag 92019, Auckland 1010, \\ New Zealand \\ ${ }^{b}$ School of Applied Sciences (Applied Chemistry), RMIT University, GPO Box 2476V, \\ Melbourne, Victoria 3001, Australia \\ E-mail: m.brimble@auckland.ac.nz
}

\begin{abstract}
The phenol catalysed Johnson orthoester-Claisen rearrangement of allylic alcohol (1R)-6, proceeds via two possible ketene-acetal transition states TS-1 and TS-2, to afford a 1:10 mixture of diastereomers. The transition state configuration of the $\mathrm{C}-1$ methyl group (axial or equatorial) is proposed to be the dominating factor dictating whether the sigmatropic rearrangement takes place from the convex or concave face of the starting material.
\end{abstract}

Keywords: Johnson-Claisen rearrangement, orthoester, oleocanthal, anti-inflammatory agent

\section{Introduction}

Olive oil, extracted solely from the fruit of olive trees (Olea europaea L.), ${ }^{1}$ is well known for its beneficial effects on human health such as reduced risk of cardiovascular diseases, age-related cognitive diseases and certain cancers. ${ }^{2}$ Although olive oil primarily contains unsaturated and saturated lipids and triacylglycerols, the minor compounds that comprise $1-2 \%$ of the total content of olive oil are of interest as many of the compounds show biological activity. ${ }^{3}$ The secoiridoid, oleocanthal (1), is a minor component of olive oil with potential for development as an anti-inflammatory agent. In-vitro studies have determined that both enantiomers of oleocanthal (1) inhibit cyclooxygenase (COX) enzymes 1 and 2 in a dose dependent manner with an efficacy similar to, if not better than, ibuprofen (2). ${ }^{4}$ The total synthesis of oleocanthal has recently been completed by Smith et $a .^{2 \mathrm{~g}, 5}$ We herein present the findings of our synthetic studies to access oleocanthal (1) using a [3,3]-sigmatropic Johnson-Claisen (orthoester) rearrangement as a key step. 


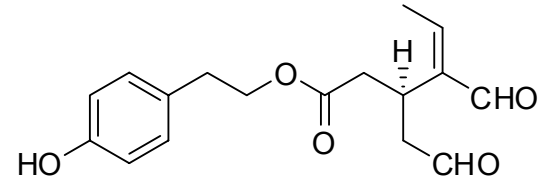

(-)-oleocanthal (1)

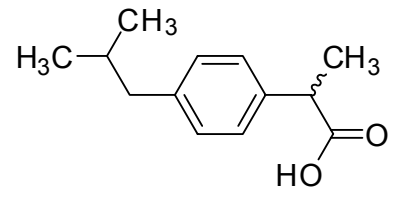

$(+/-)-$ Ibuprofen (2)

\section{Figure 1}

\section{Results and Discussion}

With a minor modification of protecting groups, our approach to oleocanthal (1) illustrated in Scheme 1 constitutes a formal synthesis based on the endgame strategy employed by Smith et $a l .^{2 \mathrm{~g}}$ Thus, in the final reaction sequence, after coupling tyrosol (3) to carboxylic acid $\mathbf{4}$ the labile dialdehyde of the natural product is liberated by acetal deprotection followed by oxidative cleavage of the resultant diol. The ethyl ester $\mathbf{5}$ is envisaged to be accessed via [3,3]-sigmatropic rearrangement of allylic alcohol 6 (Scheme 1). A cyclohexylidene acetal was chosen to protect the diol for two reasons; firstly to increase the molecular weight of the early intermediates thereby mitigating any volatility difficulties, and secondly to enhance the $\pi$-facial selectivity of the subsequent Claisen rearrangement by sterically blocking the convex face of the molecule (vide infra). Two key stereochemical elements, namely the $\mathrm{C}-5$ ' relative stereochemistry and the $E$-olefin geometry of ester $\mathbf{5}$ were envisaged to arise from the kinetically controlled Claisen rearrangement $^{6}$ of allylic alcohol $\mathbf{6}$. The aforementioned alcohol $\mathbf{6}$ is available by diastereoselective alkylation of enal 7 which itself is available via the asymmetric desymmetrization of meso-dialdehyde $\mathbf{8}$ using an organocatalytic intramolecular aldol reaction. The required dialdehyde $\mathbf{8}$ is available from a short synthetic sequence beginning from benzene. 


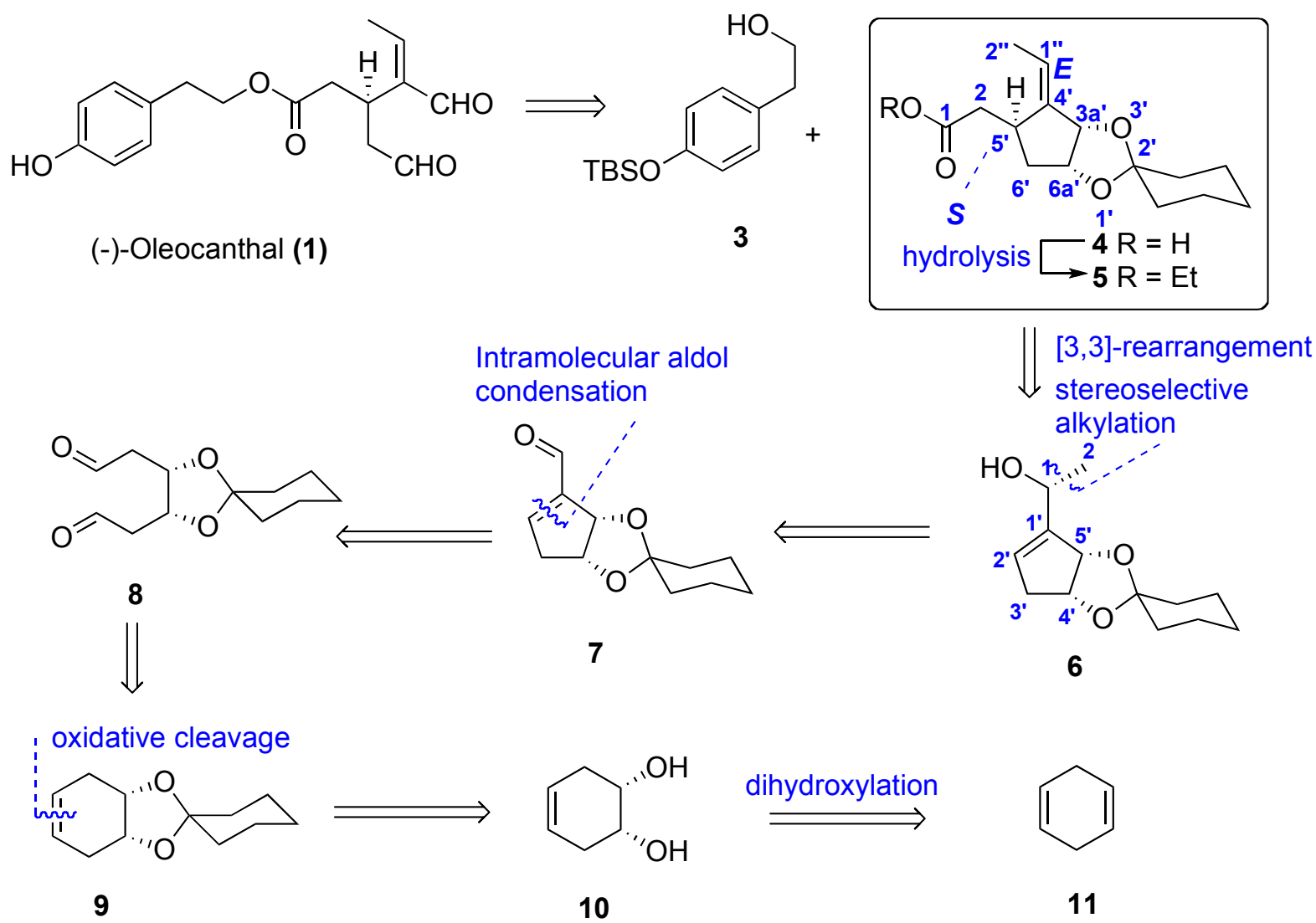

Scheme 1. Retrosynthetic strategy for the formal synthesis of oleocanthal (1).

With the above synthetic strategy in mind, the Birch reduction of benzene ${ }^{7}$ afforded cyclohexa-1,4-diene (11) as a colourless liquid. Subsequent mono-dihydroxylation of $\mathbf{1 1}^{\mathbf{8}}$ under modified Upjohn conditions ${ }^{9}$ gave syn-diol 10 as a colourless solid in $60 \%$ crude yield. Contrary to several high yielding literature syntheses, ${ }^{10}$ this capricious reaction afforded varying low yields, possibly due to the competing formation of the tetrol product. It was found that quinuclidine effectively catalysed the oxidation of cyclohexa-1,4-diene (11) affording a satisfactory yield of syn-diol 10. The use of excess diene 11 (3 eq.) relative to the amount of reoxidant facilitated a satisfactory $60 \%$ yield on a $5 \mathrm{~g}$ scale with excess cyclohexa-1,4-diene being recovered by distillation. Following acetal protection of syn-diol 10, ozonolysis furnished the unstable meso-dialdehyde $\mathbf{8}$ that was used without further purification. An alternative oxidation strategy using sodium periodate ${ }^{11}$ was also found to be effective (Scheme 2).

The aldol condensation of dialdehyde $\mathbf{8}$ to enal $\mathbf{7}$ was not straightforward. After screening an array of racemic catalysts and asymmetric organocatalysts 12-15, (table 1) a disappointingly low ( $17 \%$ over 2 steps) yield was obtained by using $25 \mathrm{~mol} \%$ piperidinium acetate. The only asymmetric catalyst that effected the aldol condensation with any notable chiral induction was (S)-trans-4-hydroxyproline (14) (Entry 11, Table 1) however the yield was too low to be employed on a practical scale. The low yield and enantiomeric excess of enal 7 is consistent with 
the data reported by Afonso et al. ${ }^{13}$ for similarly substituted compounds, and may be caused by decomposition of the precursor dialdehyde $\mathbf{8}$ by $\mathrm{E}_{1} \mathrm{cB}$ elimination of the acetal protecting group.

Addition of methyl magnesium iodide to enal $7^{14}$ afforded the desired Claisen rearrangement precursor 6 and undesired allylic alcohol 16 as a 2:1 mixture that was separated by flash chromatography (Scheme 2). Interestingly, the remote diastereoselectivity in this alkylation is thought to arise through a six-membered magnesium-chelated intermediate with the nucleophile attacking from the axial vector on the convex face.

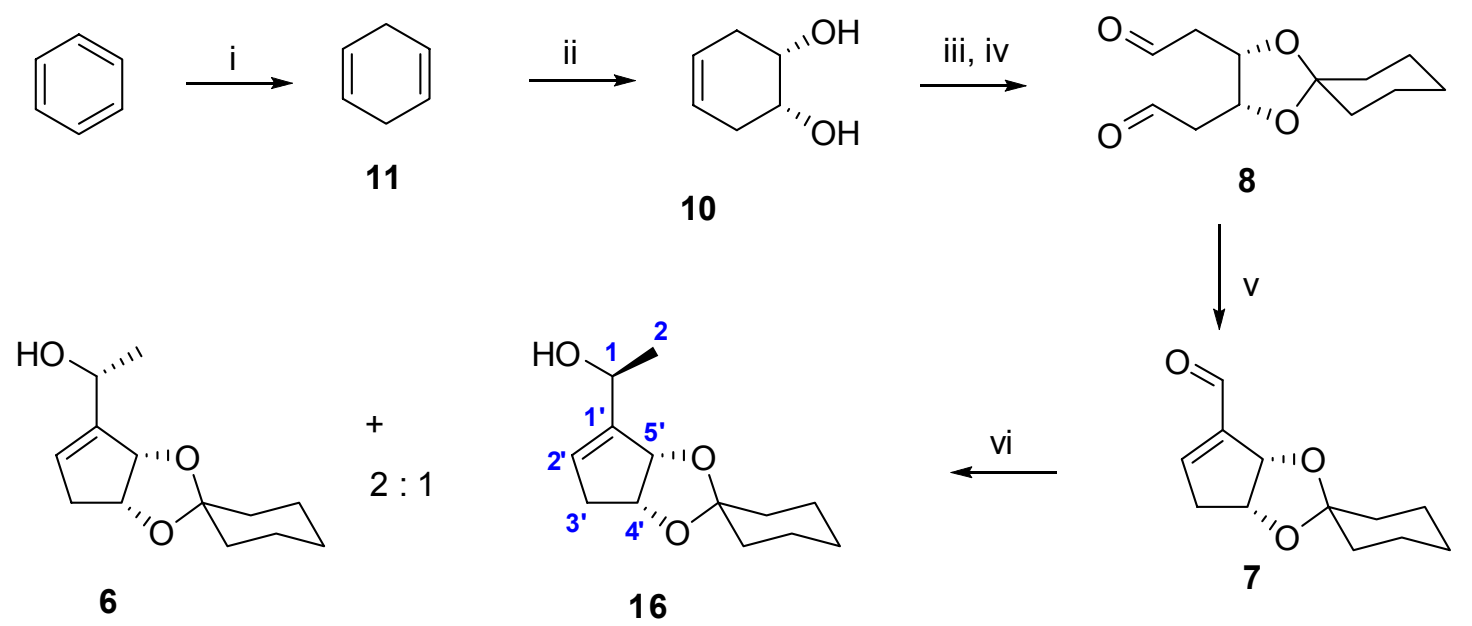

Scheme 2. i) $\mathrm{PhH}, \mathrm{Li} / \mathrm{NH}_{3}, t-\mathrm{BuOH},-40{ }^{\circ} \mathrm{C}$ to $-25{ }^{\circ} \mathrm{C}, 2 \mathrm{~h}, 78 \%$; ii) $\mathrm{OsO}_{4}, \mathrm{NMO}$, quinuclidine, $\mathrm{H}_{2} \mathrm{O}, t$ - $\mathrm{BuOH}, 10{ }^{\circ} \mathrm{C} \rightarrow \mathrm{RT}, 24 \mathrm{~h}, 60 \%$; iii) cyclohexane-1,1-diethyl acetal, $p$-TsOH, toluene, $50{ }^{\circ} \mathrm{C}, 2.5 \mathrm{~h}, 37.3 \mathrm{kPa} \rightarrow 2.13 \mathrm{kPa}, 81 \%$; iv) $\mathrm{O}_{3}, \mathrm{CH}_{2} \mathrm{Cl}_{2}$, DMS, $-78{ }^{\circ} \mathrm{C}, 0.5-1 \mathrm{~h}$; v) piperidinium acetate (0.25 mol eq.), RT, $72 \mathrm{~h}, 17 \%$ over two steps; vi) $\mathrm{CH}_{3} \mathrm{MgI}$ (2.0 eq.), THF:Et $2 \mathrm{O}$ (8:1), RT, $17 \mathrm{~h}, 51 \%$.

Table 1. Attempts to effect intramolecular aldol condensation of meso-dialdehyde 8 to enal 7

\begin{tabular}{|c|c|c|c|}
\hline Entry & Catalyst / Reagents & Reaction conditions & $\%$ Yield $^{\mathrm{a}}($ ee $\%)$ \\
\hline 1 & piperidinium acetate ( $0.25 \mathrm{~mol}$ eq. $)$ & $\mathrm{CH}_{2} \mathrm{Cl}_{2}, \mathrm{RT}, 72 \mathrm{~h}$ & 17 \\
\hline 2 & piperidine, $\mathrm{AcOH}$ (0.20 mol eq. each) & $\mathrm{CH}_{2} \mathrm{Cl}_{2}, 0^{\circ} \mathrm{C}, 3.75 \mathrm{~h}$ & 6 \\
\hline 3 & $\begin{array}{l}\text { pyrrolidine }(0.05 \text { mol. eq. }) \text { and } \mathrm{AcOH} \\
(0.25 \mathrm{~mol} \text { eq. })\end{array}$ & $\mathrm{CH}_{2} \mathrm{Cl}_{2}, \mathrm{RT}, c a .2 \mathrm{~h}$ & 5 \\
\hline 4 & piperidine (10 mol. eq.) & $\mathrm{Et}_{2} \mathrm{O}, \mathrm{RT}, 17.25 \mathrm{~h}$ & 11 \\
\hline 5 & $\mathrm{Ba}(\mathrm{OH})_{2} .8 \mathrm{H}_{2} \mathrm{O}_{(\mathrm{s})}(10 \mathrm{~mol}$. eq. $)$ & $\mathrm{Et}_{2} \mathrm{O}, \mathrm{RT}, 19 \mathrm{~h}$ & 1 \\
\hline 6 & 1,1,3,3-tetramethylguanidine (1.2 mol eq.) & $\begin{array}{c}\mathrm{CH}_{2} \mathrm{Cl}_{2}, 0^{\circ} \mathrm{C} \rightarrow \mathrm{RT} \\
2.5 \mathrm{~h}\end{array}$ & 3 \\
\hline 7 & $\begin{array}{c}\text { piperidine (0.61 mol eq.), AcOH (0.37 } \\
\text { mol eq.) }\end{array}$ & $\mathrm{CH}_{2} \mathrm{Cl}_{2}, \mathrm{RT}, 18 \mathrm{~h}$ & 6 \\
\hline
\end{tabular}


8

$$
\text { piperidine (0.47 mol eq.), AcOH (0.44 }
$$

mol eq.)

(S)-Proline (12)

9<smiles>O=C(O)[C]1CCCN1</smiles>

(S)-2-Methylproline (13)

10<smiles>CC1(C(=O)O)CCCN1</smiles>

(S)-trans-4-Hydroxyproline (14)

11 $\mathrm{HO}$,<smiles>O=C(O)C1CCCN1</smiles>

(S)-Pyrrolidin-2-yl-tetrazole

12 toluene, $0^{\circ} \mathrm{C} \rightarrow \mathrm{RT}$,

$17 \mathrm{~h}$

12 (0.2 mol eq.), $\mathrm{CH}_{2} \mathrm{Cl}_{2}, \mathrm{RT}, 19.5 \mathrm{~h}$

13 (0.2 mol eq.), $\mathrm{CH}_{2} \mathrm{Cl}_{2}, \mathrm{RT}, 19.5 \mathrm{~h}$

$6(\mathrm{ND})^{\mathrm{b}}$

14 (0.2 mol eq.), $\mathrm{CH}_{2} \mathrm{Cl}_{2}, \mathrm{RT}, 43.5 \mathrm{~h}$

15 (0.2 mol eq.), $\mathrm{CH}_{2} \mathrm{Cl}_{2}, \mathrm{RT}, 19.5 \mathrm{~h}$

${ }^{\mathrm{a}}$ Yields of enal 7 isolated after purification by flash chromatography (17\% EtOAc / n-hexane). ${ }^{\mathrm{b}} \mathrm{ND}=$ not determined due to sample decomposition.

The [3,3]-sigmatropic Claisen rearrangement is known to take place via a 6-membered chairlike transition state except in instances where steric effects favour the boat configuration. ${ }^{15}$ In the present case using allylic alcohol $\mathbf{6}$ it was considered that the chair configuration would be energetically favorable due to the avoidance of 1,4-diaxial interactions present in the boat-like configuration. Although the $\pi$-diastereofacial selectivity of Claisen rearrangements is known to be heavily dependent on the equatorial configuration of substituents, ${ }^{6,15}$ in the present case it was thought that the rearrangement may be more dependant on other steric factors. Our initial qualitative Dreiding model analysis of the Claisen transition states derived from $(1 R)-6$ and $(1 S)$ 16 revealed a significant steric interaction between the enol moiety and the acetal protecting group in transition states TS-2 and TS-4 where sigmatropic rearrangement takes place on the $\alpha$ concave face of the cyclopentane ring (Figure 2). Conversely, no such steric interaction develops if the rearrangement occurs from the $\beta$-convex face TS-1 and TS-3. Other effects, electrostatic and steric, were also expected to contribute to the transition state energy. ${ }^{15}$ 

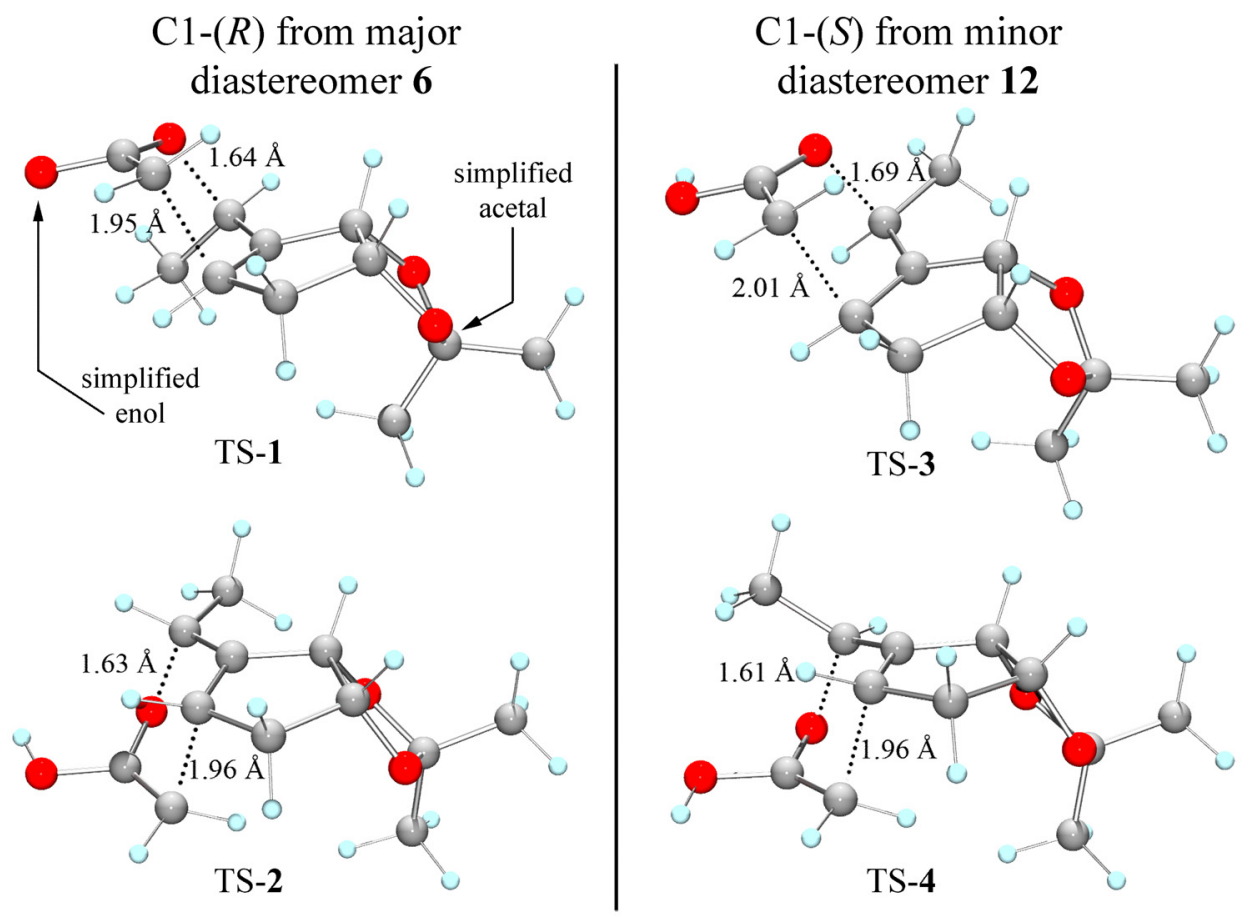

Figure 2. AM1 optimized Claisen transition states, simplified for visual clarity.

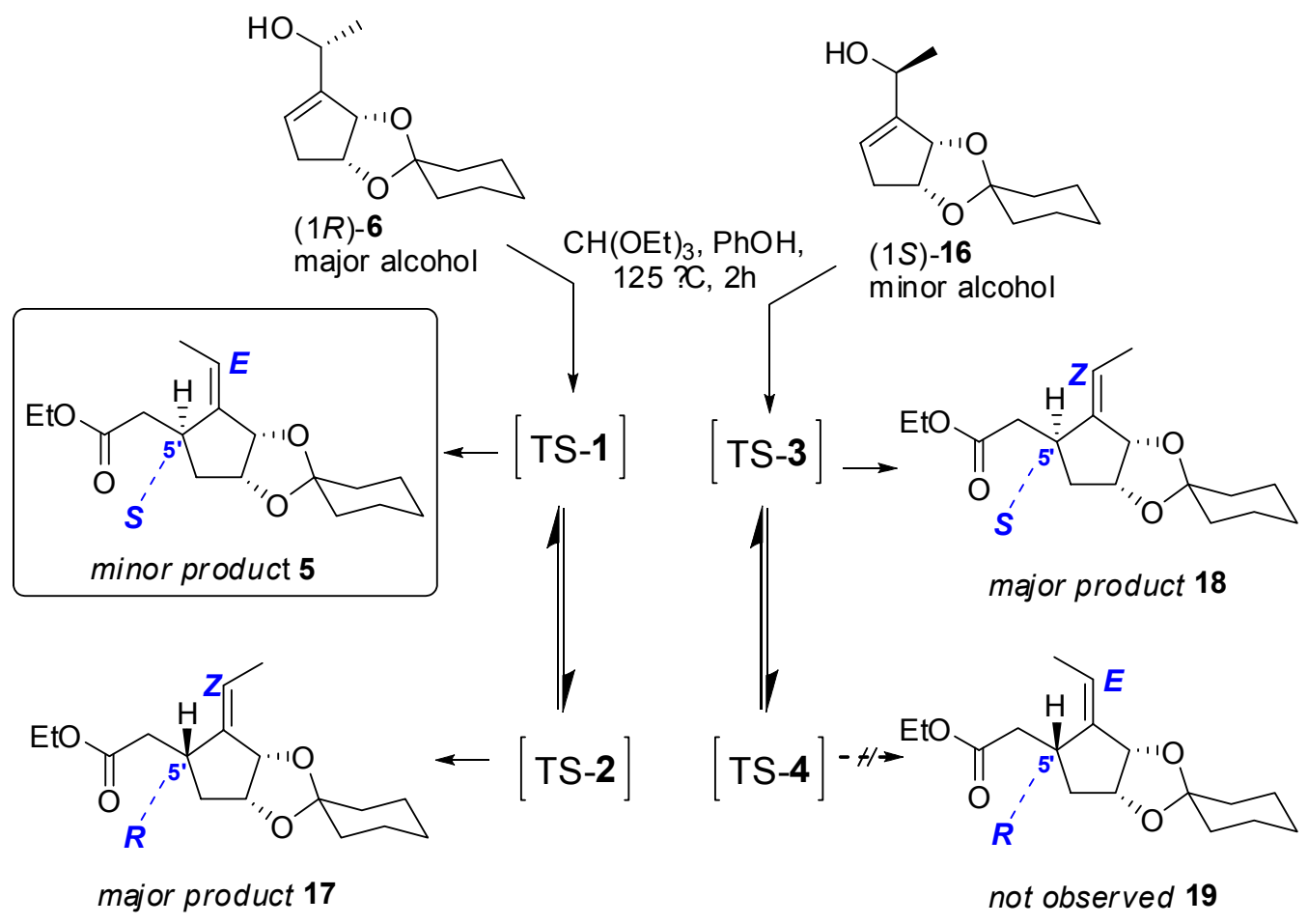

Scheme 3. Johnson-Claisen transition states for major allylic alcohol (1R)-6 and minor allylic alcohol (1S)-6. ${ }^{16}$ 
Microwave irradiation of (1R)-6 and (1S)-16 with triethyl orthoacetate in a sealed tube at 125 ${ }^{\circ} \mathrm{C}$ resulted in complete consumption of starting material after $2 \mathrm{~h}$. The weak acid phenol (pKa $10.0^{17}$ ) was chosen to catalyse the Claisen rearrangement over more conventional Brönsted acid catalysts $^{6 a}$ due to the anticipated instability of the acetal protecting group. NMR analysis of the isolated products from the rearrangement revealed a situation more complex than originally anticipated. The ${ }^{1} \mathrm{H}$ NMR spectrum of the crude product derived from $(1 R)-6$ revealed the presence of two diastereomers in a 10:1 ratio. Analysis of the NOESY spectra (Figure 2) suggested that the major product was in fact the undesired $(Z)$-configured 17 . The olefin geometry was clearly determined by the observed nOe interaction between protons of the methyl group (H-2") and $\mathrm{H}-3 \mathrm{a}^{\prime}$ and between the methine protons $\mathrm{H}-1{ }^{\prime \prime}$ and $\mathrm{H}-5^{\prime}$. The $(R)$ stereochemistry at C-5' was established by the observed nOe interaction between $\mathrm{H}-5^{\prime}$ and H-6' ${ }_{\beta}$. The minor product, which was not isolated, exhibited an ${ }^{1} \mathrm{H}$ NMR spectrum consistent with 18. The observed 10:1 ratio in favour of the undesired ethyl ester 17 suggested that the allylic alcohol, (1R)-6 primarily underwent rearrangement from the $\alpha$-concave face via TS-2, contrary to our initial predictions.

A single product was isolated from the rearrangement of $(1 S)-\mathbf{1 6}$ for which the structure was assigned on the basis of an nOe interaction between $\mathrm{H}-2$ " and H-3a', consistent with $(Z)$ - olefin geometry. The $(S)$-stereocentre at C-5' was determined by observation of a nOe interaction between H-5' and H-6' ${ }_{\alpha}^{\prime}$. Thus ethyl ester 18 was formed by Johnson-Claisen rearrangement of (1S)-16 proceeding from the $\beta$ face via TS-3 (Scheme 3).

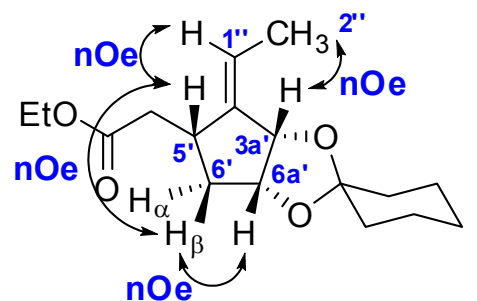

17

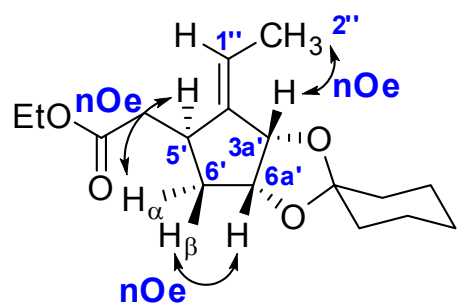

18

Figure 3. Key nOe interactions for ethyl esters $\mathbf{1 7}$ and $\mathbf{1 8 .}$

The observed formation of the (Z)-ethyl esters, $\mathbf{1 7}$ and $\mathbf{1 8}$ from the major and minor allylic alcohols, $(1 R)-\mathbf{6}$ and ( $1 S)-16$ respectively, has prompted several new considerations.

Firstly, the configuration of the $\mathrm{C}-1$ methyl group for the $\mathrm{C} 1-\mathrm{C} 1^{\prime}=\mathrm{C} 2$ ' allylic system of the transition state is now thought to be the dominating factor for $\pi$-facial selectivity through $\mathrm{A}^{1,3}$ strain or diaxial interactions. Although the cyclohexylidene acetal protecting group sterically hinders the $\alpha$-concave face of the cyclopentane ring, its affect is less significant than the axial or equatorial configuration of the C1-methyl group. In transition states derived from $(1 S)$-16 these two $\pi$-diastereofacial directing effects are matched resulting in the exclusive formation of 18 . Whereas in transition states derived from (1S)-6 the effects are mismatched leading to a mixture of isomers. Assuming that the chair-like structures illustrated in figure 2 correspond to the lowest 
energy transition states, then based on the $10: 1$ ratio of $\mathbf{1 7 : 5}$ Boltzmann statistics ${ }^{18}$ at $125^{\circ} \mathrm{C}$ would indicate that TS- $\mathbf{2} \rightarrow \mathbf{1 7}$ is more stable that TS- $\mathbf{1} \rightarrow \mathbf{5}$ by only $7.6 \mathrm{~kJ} / \mathrm{mol}$.

It is suggested that substitution of the cyclohexylidene acetal with a larger protecting group may be sufficient to sterically block the $\alpha$-concave face thus energetically favoring TS-1. This would promote rearrangement from the $\beta$ face of the ketene acetal and increase the selectivity for the desired olefinic ethyl ester 5 that would provide a key intermediate to complete a formal synthesis of (-)-oleocanthal (1). Importantly, the results reported herein provide a possibility for future investigation into synthetic analogues of oleocanthal (1) that contain a ( $Z$ )-olefin.

Based on the studies reported herein, it is proposed that 1,3-diaxial interactions between axially located substituents in the 6-membered transition states of TS-1, and TS-2 are in fact the dominant factor when determining whether the Johnson-Claisen rearrangement of alcohol (1R)-6 occurs from the $\alpha$ or $\beta$ face to furnish ethyl esters $\mathbf{1 7}$ and $\mathbf{5}$, respectively.

\section{Experimental Section}

General Procedures. All reactions were carried out in oven dried glassware under an argon or nitrogen atmosphere unless stated. Starting materials and reagents used in reactions were obtained commercially from the following chemical companies; Merck, Aldrich, Fluka, Lancaster, Sigma-Aldrich, Riedel-de Haën AG, Scharlau, Ajax Finechem., BDH Chemicals and Acros Organics, and were used without purification unless otherwise indicated. Solvents used were of lab or analytical grade and were used directly without further purification unless stated otherwise. Toluene, dichloromethane $\left(\mathrm{CH}_{2} \mathrm{Cl}_{2}\right)$, benzene $(\mathrm{PhH})$, $t$-butanol $(t$ - $\mathrm{BuOH})$, liquid ammonia $\left(\mathrm{NH}_{3}\right)$, diethyl ether $\left(\mathrm{Et}_{2} \mathrm{O}\right)$, and tetrahydrofuran $(\mathrm{THF})$ were dried and purified according to standard procedures reported in Armarego and Perrin. ${ }^{19}$ Ozone was generated from oxygen using a Fischer Model 502 ozone generator set at a flow rate of $50 \mathrm{~L} / \mathrm{h}$. Flash chromatography was carried out on Ajax Fine Chemicals (NZ) Ltd 922-200-325 mesh silica gel with the indicated solvents. The relevant fractions were combined and the solvents removed in vacuo. $n$-Hexane was distilled prior to use as an eluent for flash chromatography. Melting points were determined on a Kofler hot-stage apparatus and are uncorrected. Low resolution mass spectra were recorded using a VG-70SE mass spectrometer operating at a nominal accelerating voltage of $70 \mathrm{eV}$. Ionisation was effected using electron impact $(\mathrm{EI}+)$. High resolution mass spectra were recorded at a nominal resolution of 5000 to 10000 as appropriate. Prominent fragments are quoted in the form of $\mathrm{x}(\mathrm{y} \%)$, where $\mathrm{x}$ is the mass to charge ratio and $\mathrm{y}$ is the percent abundance relative to the base peak. Infrared spectra were obtained using a Perkin Elmer Spectrum One IR spectrometer as a liquid film in EtOAc, $\mathrm{CH}_{2} \mathrm{Cl}_{2}$ or deuterated chloroform $\left(\mathrm{CDCl}_{3}\right)$. Absorption maxima are expressed in wave numbers $\left(v, \mathrm{~cm}^{-1}\right)$. NMR spectra were recorded on either the Bruker DRX300 spectrometer operating at $300 \mathrm{MHz}$ for ${ }^{1} \mathrm{H}$ nuclei and $75 \mathrm{MHz}$ for ${ }^{13} \mathrm{C}$ nuclei or the Bruker DRX400 spectrometer operating at $400 \mathrm{MHz}$ for ${ }^{1} \mathrm{H}$ nuclei and $100 \mathrm{MHz}$ for ${ }^{13} \mathrm{C}$ nuclei. All chemical shifts are reported in parts per million 
(ppm) relative to tetramethylsilane or $\mathrm{CDCl}_{3}\left({ }^{1} \mathrm{H}\right)$ and $\mathrm{CDCl}_{3}\left({ }^{13} \mathrm{C}\right) .{ }^{1} \mathrm{H}$ NMR data is reported as chemical shift, relative integral, multiplicity ( $\mathrm{s}$, singlet; $\mathrm{d}$, doublet; $\mathrm{t}$, triplet; $\mathrm{q}$, quartet; dd, doublet of doublets; ddd, doublet of doublet of doublets; d-br, doublet-broad; ddq, doublet of doublet of quartets; m, multiplet), coupling constant ( $J \mathrm{~Hz})$ and assignment.

\section{Cyclohexa-1,4-diene (11)}

Cyclohexa-1,4-diene (11) was prepared by Birch reduction of benzene $(89.0 \mathrm{~mL}, 1.00 \mathrm{~mol})$ according to the procedure reported by Brandsma et al. ${ }^{7}$ to afford the title compound $\mathbf{1 1}$ as a colourless liquid $\left(62.5 \mathrm{~g}, 78 \%\right.$ ) in two fractions (bp. $86-88{ }^{\circ} \mathrm{C} / 101.3 \mathrm{kPa}$ and b.p. $88-98$ ${ }^{\circ} \mathrm{C} / 101.3 \mathrm{kPa}$ ). Bp. $86-88{ }^{\circ} \mathrm{C} / 101.3 \mathrm{kPa}, 88-98{ }^{\circ} \mathrm{C} / 101.32 \mathrm{kPa}$ (lit. b.p. ${ }^{20} 85.5^{\circ} \mathrm{C} / 101.3 \mathrm{kPa}$ ). The ${ }^{1} \mathrm{H}$ and ${ }^{13} \mathrm{C}$ NMR data obtained was in agreement with that reported in the literature. ${ }^{21}$

\section{cis-Cyclohex-4-ene-1,2-diol (10)}

To a solution of cyclohexa-1,4-diene (11) $(19.5 \mathrm{~g}, 243 \mathrm{mmol})$ in water $(20 \mathrm{~mL})$ and $t$-BuOH $(100 \mathrm{~mL})$ was added quinuclidine $(2.90 \mathrm{~g}, 26.0 \mathrm{mmol})$ and freshly prepared $N$-methylmorpholine $N$-oxide 9 (9.50 g, $81.0 \mathrm{mmol})$. The reaction was cooled to $c a .10{ }^{\circ} \mathrm{C}$ then osmium tetroxide $\left(\mathrm{OsO}_{4}\right)$ was added as a 2.5 wt. \% solution in $t$-butanol $(3.10 \mathrm{~g}, c a .3 .85 \mathrm{~mL} 12.2 \mathrm{mmol})$. The reaction mixture was stirred for $24 \mathrm{~h}$ at room temperature. A short path condenser was attached and excess starting material 11 was recovered by distillation. Saturated $\mathrm{NaCl}(50 \mathrm{~mL})$ was added and the aqueous layer extracted with EtOAc $(4 \times 80 \mathrm{~mL})$. The combined organic extracts were dried over $\mathrm{Na}_{2} \mathrm{SO}_{4}$ and evaporated in vacuo to obtain the title compound $\mathbf{1 0}$ as an off-white crystalline solid $(5.5 \mathrm{~g}, 60 \%)$ which was used directly without further purification. Mp. 80-83 ${ }^{\circ} \mathrm{C}$ (lit. mp. $\left.{ }^{22} 69-70{ }^{\circ} \mathrm{C}\right) ; R_{f}\left(20 \% n\right.$-hexane/EtOAc) 0.32 . The ${ }^{1} \mathrm{H}$ and ${ }^{13} \mathrm{C}$ NMR data obtained were in agreement with that reported in the literature. ${ }^{10,21}$

\section{Cyclohexane-1,1-diethyl acetal $(12)^{22}$}

To a three-necked $500 \mathrm{~mL}$ round bottom flask equipped with a mechanical stirrer and Teflon paddle was added cyclohexanone $(31.7 \mathrm{~mL}, 306 \mathrm{mmol})$ and triethyl orthoformate $(152 \mathrm{~mL}, 917$ mmol). The mixture was immersed in an ice bath. Amberlyst-15 ion-exchange resin was washed prior to use with $1 \mathrm{M} \mathrm{NaOH}(50 \mathrm{~mL})$, followed by $1 \mathrm{M} \mathrm{HCl}(50 \mathrm{~mL})$. The process was repeated twice and the washed resin was rinsed with distilled $\mathrm{H}_{2} \mathrm{O}$ until the eluant was neutral. The washed Amberlyst beads ( $c a .7 .5 \mathrm{~g}$ ) were then added to the mixture and the reaction stirred for $3-4 \mathrm{~h}$ at $0-5^{\circ} \mathrm{C}$. The resin was removed by filtration to obtain a yellow filtrate. The excess triethyl orthoformate (bp. $41-54^{\circ} \mathrm{C} / 2.3 \mathrm{kPa}$ ) was removed by distillation under high vacuum removed to afford the title compound $12\left(76-82{ }^{\circ} \mathrm{C} / 2.3 \mathrm{kPa}\right)$ as a colourless liquid $(30 \mathrm{~g}, 58 \%)$ Bp. $76-82{ }^{\circ} \mathrm{C} / 2.3 \mathrm{kPa}$ (lit. bp. $\left.{ }^{23} 85-88{ }^{\circ} \mathrm{C} / 2.5 \mathrm{kPa}\right) ; R_{f}\left(3 \%\right.$ EtOAc/ $n$-hexane) 0.39 . The ${ }^{1} \mathrm{H}$ and ${ }^{13} \mathrm{C}$ NMR data obtained were in agreement with that reported in the literature. ${ }^{23}$ 


\section{(4RS,5SR)-4,5-(1,1-Cyclohexylidenedioxy)-1-cyclohexene (9)}

To a $250 \mathrm{~mL}$ round bottom flask containing syn-diol $10(5.50 \mathrm{~g}, 48.2 \mathrm{mmol})$, diethyl acetal $12(10.0 \mathrm{~g}, 58.1 \mathrm{mmol})$ and a magnetic stirrer bar, was added $p$-TsOH $(461 \mathrm{mg}, 2.42 \mathrm{mmol})$ and dry toluene $(c a .30-50 \mathrm{~mL})$. The reaction mixture was stirred for $1.25 \mathrm{~h}\left(50^{\circ} \mathrm{C}\right)$ under argon. Distillation apparatus (Vigreux column and short path condenser) was assembled and the reaction allowed to stir for $1 \mathrm{~h}$ under reduced pressure $(c a .37 \mathrm{kPa})$ or until the reaction was complete as indicated by TLC. The reaction was driven to completion by applying high vacuum (2.1-2.7 kPa, 10-15 $\mathrm{min})$. The reaction was quenched with saturated sodium bicarbonate (50-70 $\mathrm{mL})$ and stirred vigorously for $0.5 \mathrm{~h}$. The aqueous layer was extracted with EtOAc ( $3 \times 100 \mathrm{~mL})$ and the combined organic extracts were washed with saturated $\mathrm{NaCl}(c a .100 \mathrm{~mL})$ and dried over $\mathrm{MgSO}_{4}$. The solvent was evaporated in vacuo to afford a crude black residue. Purification of the residue by flash chromatography ( $3 \% \mathrm{EtOAc} / n$-hexane) gave the title compound 9 as a colourless oil (7.6 g, 81\%). $R_{f}\left(3 \% \mathrm{EtOAc} / n\right.$-hexane) $0.30 ;{ }^{1} \mathrm{H}$ NMR $\left(300 \mathrm{MHz}, \mathrm{CDCl}_{3}\right) \delta 1.39-$ $1.64(10 \mathrm{H}, \mathrm{m}$, cyclohexylidene $), 2.24-2.30\left(4 \mathrm{H}, \mathrm{m},=\mathrm{CHCH}_{2} \mathrm{CH}\right), 4.30-4.34(2 \mathrm{H}, \mathrm{m}$, $\left.=\mathrm{CHCH}_{2} \mathrm{CH}\right), 5.76-5.78\left(2 \mathrm{H}, \mathrm{t}, J 3.0 \mathrm{~Hz},=\mathrm{CHCH}_{2} \mathrm{CH}\right) ;{ }^{13} \mathrm{C} \mathrm{NMR}\left(75 \mathrm{MHz}, \mathrm{CDCl}_{3}\right) \delta 23.7$, 24.1, 25.3, 28.5, 34.4, 36.9, 72.5, 108.1, 125.4. The ${ }^{1} \mathrm{H}$ NMR data obtained was in agreement with that reported in the literature. ${ }^{24}$

\section{(4RS,5SR)-1-Formyl-4,5-(cyclohexyldioxy)cyclopent-1-ene (7)}

A $100 \mathrm{~mL}$ round bottom flask charged with a solution of olefin $9(1.4 \mathrm{~g}, 7.21 \mathrm{mmol})$ in $\mathrm{CH}_{2} \mathrm{Cl}_{2}$ $\left(20 \mathrm{~mL}\right.$ ), was cooled to $-78^{\circ} \mathrm{C}$. Ozone was bubbled through the solution (flow rate: $50 \mathrm{~L} / \mathrm{h}$ ) until the appearance of a persistent faint blue colour. The excess ozone was purged with argon and quenched with excess dimethyl sulfide $(c a .0 .5 \mathrm{~mL})$. The reaction mixture was purged once more with argon and allowed to warm to room temperature over $1 \mathrm{~h}$. Attempts to isolate dialdehyde $\mathbf{8}$ were unsuccessful as the dialdehyde was found to rapidly decompose on silica, hence the crude reaction mixture was carried directly to the aldol condensation step.

Piperidine $(123 \mathrm{mg}, 1.44 \mathrm{mmol})$ and glacial acetic acid $(86.4 \mathrm{mg}, 1.44 \mathrm{mmol})$ were mixed in a separate flask cooled to $0{ }^{\circ} \mathrm{C}$, to afford piperidinium acetate as a white powder. The piperidinium acetate thus prepared $(263 \mathrm{mg}, 1.81 \mathrm{mmol})$ was added to the solution of dialdehyde 8 in $\mathrm{CH}_{2} \mathrm{Cl}_{2}$ and the resultant mixture left to stir for $72 \mathrm{~h}$, forming a dark brown suspension. The reaction mixture was washed with $10 \%$ aqueous sodium bicarbonate $(2 \times 25 \mathrm{~mL})$. The aqueous phase was saturated with solid $\mathrm{NaCl}(\mathrm{ca} .5 \mathrm{~g}$ ) to break up any emulsions then extracted with toluene $(3 \times 50 \mathrm{~mL})$. The combined organic extracts were washed with saturated $\mathrm{NaCl}(100$ $\mathrm{mL}$ ), dried over $\mathrm{Na}_{2} \mathrm{SO}_{4}$ and the solvent evaporated in vacuo to obtain a crude dark brown oil. Purification of the crude material by flash chromatography (17\% EtOAc/n-hexane) afforded the title product 7 as a colourless oil which crystallised at low temperature to afford colourless crystals $\left(249.7 \mathrm{mg}, 17 \%\right.$ over two steps). Mp. $56-66{ }^{\circ} \mathrm{C} ; R_{f}(17 \%$ EtOAc/ $n$-hexane) 0.23 ; IR (liquid film) v $2934 \mathrm{~s}(\mathrm{C}-\mathrm{H}), 2855 \mathrm{w}(\mathrm{C}-\mathrm{H}), 1687 \mathrm{vs}(\mathrm{C}=\mathrm{O}), 1618 \mathrm{w}(\mathrm{C}=\mathrm{C}), 1449 \mathrm{w}, 1366 \mathrm{w}$, $1161 \mathrm{~m}, 1102 \mathrm{~m}(\mathrm{C}-\mathrm{O}-\mathrm{C}), 940 \mathrm{w} \mathrm{cm}^{-1} ;{ }^{1}\left(300 \mathrm{MHz}, \mathrm{CDCl}_{3}\right) \delta 1.49-1.57(10 \mathrm{H}, \mathrm{m}$, cyclohexylidene $), 2.73-2.76\left(2 \mathrm{H}, \mathrm{m},=\mathrm{CHC}_{2} \mathrm{CH}\right), 4.78-4.81\left(1 \mathrm{H}, \mathrm{m}, \mathrm{CH}_{2} \mathrm{C} \underline{\mathrm{H}}-\mathrm{O}\right), 5.24-$ 
$5.26(1 \mathrm{H}, \mathrm{d}, J 6.0 \mathrm{~Hz},=\mathrm{CC} \underline{\mathrm{H}}-\mathrm{O}), 6.80-6.82\left(1 \mathrm{H}, \mathrm{t}, J 3.0 \mathrm{~Hz}, \mathrm{C}=\mathrm{C}_{\underline{H}} \mathrm{CH}_{2}\right), 9.76(1 \mathrm{H}, \mathrm{s}, \mathrm{C} \underline{\mathrm{HO}})$;

${ }^{13} \mathrm{C}$ NMR $\left(75 \mathrm{MHz}, \mathrm{CDCl}_{3}\right) \delta 23.5\left(\mathrm{CH}_{2}\right), 23.9\left(\mathrm{CH}_{2}\right), 24.9\left(\mathrm{CH}_{2}\right), 34.5\left(\mathrm{CH}_{2}\right), 36.8\left(\mathrm{CH}_{2}\right), 39.1$ $\left(\mathrm{CH}_{2}\right), 77.4(\mathrm{CH}), 80.9(\mathrm{CH}), 111.4(\mathrm{C}), 145.6(\mathrm{C}), 151.1(\mathrm{CH}), 188.7(\mathrm{CH}) ; \mathrm{MS} m / z(\%) 208$ $\left(\mathrm{M}^{+}, 39\right), 179\left(\mathrm{M}^{+}-\mathrm{CHO}, 11\right), 165(81), 152$ (3), 55 (100), 41 (20); HRMS calculated for $\mathrm{C}_{12} \mathrm{H}_{16} \mathrm{O}_{3} \mathrm{M}^{+}$: 208.1099, found: 208.1094.

\section{(4RS,5SR)-1-[4,5-(Cyclohexyldioxy)cyclopent-1-enyl]ethanol (6). Procedure modified from} Köhler et al. ${ }^{11}$

To a $5 \mathrm{~mL}$ two-necked round bottom flask containing a solution of $\mathrm{CH}_{3} \mathrm{MgI}(\mathrm{ca} .1 .5 \mathrm{M}, 1.1 \mathrm{~mL}$ ) in dry $\mathrm{Et}_{2} \mathrm{O}(1 \mathrm{~mL})$ under argon was added a solution of enal $7(167 \mathrm{mg}, 0.80 \mathrm{mmol})$ in THF $(130 \mu \mathrm{L})$ at room temperature over $20 \mathrm{~min}$ by syringe. The reaction mixture formed a thick offwhite precipitate and was allowed to stir at room temperature for $17.5 \mathrm{~h}$. The reaction mixture was diluted with dry THF ( $2 \mathrm{~mL})$, quenched with ice ( $c a .1 .6 \mathrm{~g})$, and stirred vigorously to form a yellow thick gel. The gel was treated with solid ammonium chloride ( $c a .1-2 \mathrm{~g})$ and stirred vigorously. The aqueous layer was extracted with EtOAc $(20 \mathrm{~mL}$, then $2 \times 5 \mathrm{~mL})$ and the combined organic extracts were washed with saturated $\mathrm{NaCl}(20 \mathrm{~mL})$ that were back extracted with EtOAc $(20 \mathrm{~mL})$. The organic extracts were combined, dried over $\mathrm{Na}_{2} \mathrm{SO}_{4}$ and evaporated in vacuo to give a yellow oil. TLC analysis of the combined extracts indicated that deprotection of the cyclohexylidene had taken place and 2-D TLC analysis showed slight degradation on silica. The crude material was purified by flash chromatography (17-20\% EtOAc $/ n$-hexane, contains a trace amount of triethylamine) to afford a diastereomeric mixture of the title compound $\mathbf{6}$, as a colourless oil (total yield $91.0 \mathrm{mg}, 51 \%$ ). The mixture of diastereomers proved difficult to separate by flash chromatography due to decomposition on silica (major diastereomer, $43.5 \mathrm{mg}$, $24 \%$; minor diasteromer, $24.5 \mathrm{mg}, 14 \%)$.

Major diastereomer (1R)-6: $R_{f}(17 \%$ EtOAc $/ n$-hexane) $0.17,(20 \%$ EtOAc/ $n$-hexane) 0.22 ; IR (liquid film) v $3388 \mathrm{br}(\mathrm{O}-\mathrm{H}), 2932 \mathrm{~s}(\mathrm{C}-\mathrm{H}), 2858 \mathrm{w}(\mathrm{C}-\mathrm{H}), 1448 \mathrm{~m}, 1366 \mathrm{~m}, 1160 \mathrm{~m}(\mathrm{C}-\mathrm{O}-$ C), 1093 vs (C-O), $1035 \mathrm{w}, 940 \mathrm{~m}, 908 \mathrm{~m}, 730 \mathrm{~s} \mathrm{~cm}^{-1}$; ${ }^{1} \mathrm{H}$ NMR $\left(300 \mathrm{MHz}, \mathrm{CDCl}_{3}\right) \delta 1.39-1.41$ $\left(3 \mathrm{H}, \mathrm{d}, J 6.0 \mathrm{~Hz} \mathrm{CHCH}_{3}\right), 1.58-1.61(10 \mathrm{H}, \mathrm{m}$, cyclohexylidene), 2.53-2.55 (2H, m, $\left.=\mathrm{CHCH}_{2} \mathrm{CH}\right), 4.49-4.56\left(1 \mathrm{H}, \mathrm{q}, J 6.0 \mathrm{~Hz} \mathrm{CH}_{3} \mathrm{CHOH}\right), 4.75-4.79\left(1 \mathrm{H}, \mathrm{m}, \mathrm{CH}_{2} \mathrm{C} \underline{\mathrm{H}}-\mathrm{O}\right), 5.17-$ $5.19(1 \mathrm{H}, \mathrm{d}, J 6.0 \mathrm{~Hz},=\mathrm{CC} \underline{\mathrm{H}}-\mathrm{O}), 5.59-5.61\left(1 \mathrm{H}, \mathrm{m}, \mathrm{C}=\mathrm{C}_{\underline{H C H}}\right) ;{ }^{13} \mathrm{C} \mathrm{NMR}\left(75 \mathrm{MHz}, \mathrm{CDCl}_{3}\right)$

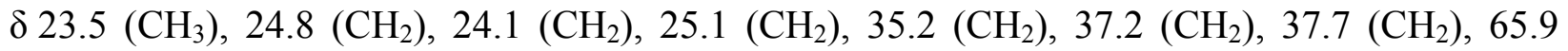
$(\mathrm{CHOH}), 77.9(\mathrm{CH}), 83.9(\mathrm{CH}), 111.0(\mathrm{C}), 125.8(\mathrm{CH}), 146.1(\mathrm{C})$; MS m/z (\%) 225, $\left(\mathrm{MH}^{+}, 15\right)$, 224, ( $\left.\mathrm{M}^{+}, 100\right), 210$, (11), 195 (13), 181 (88), 163 (25), 109 (86), 95 (20), 83 (20), 81 (32), 67 (25), 55 (62), 43 (65); HRMS calculated for $\mathrm{C}_{13} \mathrm{H}_{20} \mathrm{O}_{3} \mathrm{M}^{+}: 224.1412$, found: 224.1412.

Minor diastereomer (1S)-16: $R_{f}(17 \% \mathrm{EtOAc} / n$-hexane) $0.27,(20 \% \mathrm{EtOAc} / n$-hexane) 0.30 ; IR (liquid film) v $3434 \mathrm{br}(\mathrm{O}-\mathrm{H}), 2931 \mathrm{~s}(\mathrm{C}-\mathrm{H}), 2853 \mathrm{w}(\mathrm{C}-\mathrm{H}), 1448 \mathrm{~m}, 1365 \mathrm{~m}, 1161 \mathrm{~m}(\mathrm{C}-\mathrm{O}-$ C), $1095 \mathrm{~s}(\mathrm{C}-\mathrm{O}), 1047 \mathrm{w}, 941 \mathrm{~m} \mathrm{~cm}^{-1} ;{ }^{1} \mathrm{H}$ NMR $\left(400 \mathrm{MHz}, \mathrm{CDCl}_{3}\right) \delta 1.375-1.39(3 \mathrm{H}, \mathrm{d}, J 6.0$ $\left.\mathrm{Hz} \mathrm{CHC} \underline{H}_{3}\right), 1.59-1.63\left(10 \mathrm{H}, \mathrm{m}\right.$, cyclohexylidene), 2.48-2.61 $\left(2 \mathrm{H}, \mathrm{m},=\mathrm{CHCH}_{2} \mathrm{CH}\right), 2.73(1 \mathrm{H}, \mathrm{s}$, $\mathrm{CHOH}), 4.52-4.51\left(1 \mathrm{H}, \mathrm{m}, \mathrm{CH}_{3} \mathrm{C} \underline{\mathrm{HOH}}\right), 4.76-4.78\left(1 \mathrm{H}, \mathrm{m}, \mathrm{CH}_{2} \mathrm{C} \underline{\mathrm{H}}-\mathrm{O}\right), 5.07-5.09(1 \mathrm{H}$, $\mathrm{d}, J 8.0 \mathrm{~Hz},=\mathrm{CC} \underline{\mathrm{H}}-\mathrm{O}), 5.61-5.63\left(1 \mathrm{H}, \mathrm{m}, \mathrm{C}=\mathrm{CHCH}_{2}\right) ;{ }^{13} \mathrm{C} \mathrm{NMR}\left(100 \mathrm{MHz}, \mathrm{CDCl}_{3}\right) \delta 21.5$ 
$\left(\mathrm{CH}_{3}\right), 23.8\left(\mathrm{CH}_{2}\right), 24.1\left(\mathrm{CH}_{2}\right), 25.1\left(\mathrm{CH}_{2}\right), 35.2\left(\mathrm{CH}_{2}\right), 37.2\left(\mathrm{CH}_{2}\right), 37.5\left(\mathrm{CH}_{2}\right), 65.8(\mathrm{CH}), 78.0$ (CH), $85.7(\mathrm{CH}), 111.1(\mathrm{C}), 124.9(\mathrm{CH}), 146.0(\mathrm{C})$; MS m/z (\%) $225\left(\mathrm{MH}^{+}, 16\right), 224,\left(\mathrm{M}^{+}, 100\right)$, 195 (12), 181 (90), 163 (38), 109 (80), 81 (34), 67 (27), 55 (53), 43 (56); HRMS calculated for $\mathrm{C}_{13} \mathrm{H}_{20} \mathrm{O}_{3} \mathrm{M}^{+}:$224.1412, found 224.1408.

\section{Ethyl 2-((3a'SR,5'R,6a' $R S, Z)-4^{\prime}$-Ethylidenetetrahydro-3a' $H$-spiro[cyclohexane-1,2'- cyclopenta $[d]\left[1^{\prime}, 3^{\prime}\right]$ dioxole $\left.]-5 '-y l\right)$ acetate (17) (derived from major allylic alcohol (1R)-6)}

A stirred solution of allylic alcohol $(1 R)-6(7.0 \mathrm{mg}, 31 \mu \mathrm{mol})$ and phenol $(3.0 \mathrm{mg}, 32 \mu \mathrm{mol})$ in triethyl orthoformate $(2.5 \mathrm{~g}, 15 \mathrm{mmol})$ was heated in a microwave reactor to $125{ }^{\circ} \mathrm{C}$. After $2 \mathrm{~h}$, the solvent was removed in vacuo and the residue was purified by flash chromatography $(9 \%$ EtOAc/n-hexane) to afford the title compound 18 as a colourless oil $(8.4 \mathrm{mg}, 91 \%) . \mathrm{R}_{f} 0.39(9 \%$ EtOAc/n-hexane); IR (liquid film) v $2932 \mathrm{~s}(\mathrm{C}-\mathrm{H}), 1736$ vs $(\mathrm{C}=\mathrm{O}), 1160 \mathrm{~m}, 1032 \mathrm{~m}(\mathrm{O}-\mathrm{C}-\mathrm{C})$ $\mathrm{cm}^{-1}$; ${ }^{1} \mathrm{H}$ NMR $\left(300 \mathrm{MHz}, \mathrm{CDCl}_{3}\right) \delta 1.25\left(3 \mathrm{H}, \mathrm{d}, J 7.1 \mathrm{~Hz}, \mathrm{OCH}_{2} \mathrm{CH}_{3}\right), 1.32-1.75(10 \mathrm{H}, \mathrm{m}$, cyclohexylidene), $1.77\left(3 \mathrm{H}\right.$, ddd, $\left.J 0.5,1.2,6.9 \mathrm{~Hz},=\mathrm{CHCH}_{3}\right), 1.79(1 \mathrm{H}$, ddd, $J 3.1,3.1,14.2 \mathrm{~Hz}$, $=\mathrm{CHCH}\left(\underline{\mathrm{H}}_{\alpha}\right) \mathrm{CH}-\mathrm{O}, 1.98\left(1 \mathrm{H}, \mathrm{ddd}, J 5.8,7.7,14.4 \mathrm{~Hz}, \mathrm{CHCH}\left(\underline{\mathrm{H}}_{\beta}\right) \mathrm{CH}-\mathrm{O}\right), 2.63(2 \mathrm{H}, \mathrm{d}, J 7.7 \mathrm{~Hz}$, $\mathrm{C}(=\mathrm{O}) \underline{\mathrm{C}}_{2}, 2.87-2.98\left(1 \mathrm{H}, \mathrm{m},=\mathrm{CC}_{\underline{H C H}}\right), 4.12\left(2 \mathrm{H}, \mathrm{q}, J 7.1 \mathrm{~Hz}, \mathrm{OC}_{2} \mathrm{CH}_{3}\right), 4.65(1 \mathrm{H}, \mathrm{ddd}, J$ 2.2, 5.9, $\left.5.9 \mathrm{~Hz}, \mathrm{CH}_{2} \mathrm{C} \underline{\mathrm{H}}-\mathrm{O}\right), 4.99(1 \mathrm{H}, \mathrm{d}-\mathrm{br}, J 6.0 \mathrm{~Hz},=\mathrm{CC} \underline{\mathrm{H}}-\mathrm{O}), 5.63$ (1H, ddq, $J 1.5,1.5,6.8$ $\left.\mathrm{Hz}, \mathrm{C}=\mathrm{CHCH}_{3}\right) ;{ }^{13} \mathrm{C} \mathrm{NMR}\left(75 \mathrm{MHz}, \mathrm{CDCl}_{3}\right) \delta 14.3\left(\mathrm{CH}_{3}\right), 14.5\left(\mathrm{CH}_{3}\right), 23.7\left(\mathrm{CH}_{2}\right), 24.1\left(\mathrm{CH}_{2}\right)$, $25.2\left(\mathrm{CH}_{2}\right), 33.5\left(\mathrm{CH}_{2}\right), 36.0\left(\mathrm{CH}_{2}\right), 36.7\left(\mathrm{CH}_{2}\right), 40.2(\mathrm{CH}), 41.4\left(\mathrm{CH}_{2}\right), 60.2\left(\mathrm{CH}_{2}\right), 78.3(\mathrm{CH})$, $79.9(\mathrm{CH}), 111.5(\mathrm{C}), 124.3(\mathrm{CH}), 143.6(\mathrm{C}), 173.0$ (C); MS m/z (\%) $294\left(\mathrm{M}^{+}, 55\right), 251\left(\mathrm{M}^{+}-\right.$ $\mathrm{CH}_{2} \mathrm{CH}_{2} \mathrm{O}$, 63), 197 (58), 179 (36), 151 (34), 123 (48), 105 (43), 92 (30), 55 (100), 41 (41); HRMS calculated for $\mathrm{C}_{17} \mathrm{H}_{26} \mathrm{O}_{4} \mathrm{M}^{+}$: 294.1831, found 294.1832.

Ethyl 2-((3a'SR,5'S,6a' $R S, Z)-4$ '-Ethylidenetetrahydro-3a' $H$-spiro[cyclohexane-1,2'cyclopenta $[d]\left[1^{\prime}, 3^{\prime}\right]$ dioxole]-5'-yl)acetate (18) (derived from minor allylic alcohol (1S)-16)

A stirred solution of allylic alcohol $(1 S)-6(12.0 \mathrm{mg}, 53 \mu \mathrm{mol})$ and phenol $(4.0 \mathrm{mg}, 43 \mu \mathrm{mol})$ in triethyl orthoformate $(2.5 \mathrm{~g}, 15 \mathrm{mmol})$ was heated in a microwave reactor to $125^{\circ} \mathrm{C}$. After $2 \mathrm{~h}$, the solvent was removed in vacuo and the residue was purified by flash chromatography $(9 \%$ EtOAc/n-hexane) to afford the title compound 19 as a colourless oil $(10.0 \mathrm{mg}, 70 \%) . \quad \mathrm{R}_{f} 0.39$ (9\% EtOAc/n-hexane); IR (liquid film) $2933 \mathrm{~s}(\mathrm{C}-\mathrm{H}), 1732 \mathrm{vs}(\mathrm{C}=\mathrm{O}), 1447 \mathrm{w}, 1369 \mathrm{~m}, 1159 \mathrm{~m}$, $1032 \mathrm{~m}(\mathrm{O}-\mathrm{C}-\mathrm{C}) \mathrm{cm}^{-1} ;{ }^{1} \mathrm{H} \mathrm{NMR}\left(300 \mathrm{MHz}, \mathrm{CDCl}_{3}\right) \delta 1.26\left(3 \mathrm{H}, \mathrm{t}, J 7.1 \mathrm{~Hz}, \mathrm{OCH}_{2} \mathrm{CH}_{3}\right), 1.30$ (1H, ddd, $J$ 5.0, 11.4, $\left.11.2 \mathrm{~Hz}, \mathrm{CHCH}\left(\underline{\mathrm{H}}_{\beta}\right) \mathrm{CH}-\mathrm{O}\right), 1.35-1.69(10 \mathrm{H}, \mathrm{m}$, cyclohexylidene), 1.79 $\left(3 \mathrm{H}, \mathrm{dd}, J 2.5,6.9 \mathrm{~Hz},=\mathrm{CHCH}_{3}\right), 2.15(1 \mathrm{H}, \mathrm{dd}, J 6.1,14.9 \mathrm{~Hz}, \mathrm{C}(=\mathrm{O}) \mathrm{C} \underline{\mathrm{H}}(\mathrm{H})), 2.19\left(1 \mathrm{H}, \mathrm{dd},{ }^{\mathrm{a}} J\right.$ $\left.6.5,13.9 \mathrm{~Hz},=\mathrm{CHCH}\left(\underline{\mathrm{H}}_{\alpha}\right) \mathrm{CH}-\mathrm{O}\right), 2.61(1 \mathrm{H}, J 5.3,14.9 \mathrm{~Hz}, \mathrm{C}(=\mathrm{O}) \mathrm{C}(\mathrm{H}) \underline{\mathrm{H}}), 3.02-3.16(1 \mathrm{H}, \mathrm{m}$, $\left.=\mathrm{CC}_{\underline{H C H}}\right), 4.14\left(2 \mathrm{H}, \mathrm{q}, J 7.1 \mathrm{~Hz}, \mathrm{OCH}_{2} \mathrm{CH}_{3}\right), 4.61\left(1 \mathrm{H}, \mathrm{dd}, J 5.3,5.3 \mathrm{~Hz}, \mathrm{CH}_{2} \mathrm{C} \underline{\mathrm{H}}-\mathrm{O}\right), 5.01$ $(1 \mathrm{H}, \mathrm{d}, J 5.7 \mathrm{~Hz},=\mathrm{CC} \underline{\mathrm{H}}-\mathrm{O}), 5.38\left(1 \mathrm{H}, \mathrm{ddq}, J 1.4,2.5,6.7 \mathrm{~Hz}, \mathrm{C}=\mathrm{C}^{\mathrm{HCH}}{ }_{3}\right) ;{ }^{13} \mathrm{C} \mathrm{NMR}(75 \mathrm{MHz}$, $\left.\mathrm{CDCl}_{3}\right) \delta 14.1\left(\mathrm{CH}_{3}\right), 14.2\left(\mathrm{CH}_{3}\right), 23.8\left(\mathrm{CH}_{2}\right), 24.1\left(\mathrm{CH}_{2}\right), 25.3\left(\mathrm{CH}_{2}\right), 33.9\left(\mathrm{CH}_{2}\right), 36.0(\mathrm{CH})$, $36.3\left(\mathrm{CH}_{2}\right), 36.8\left(\mathrm{CH}_{2}\right), 37.1\left(\mathrm{CH}_{2}\right), 60.4\left(\mathrm{CH}_{2}\right), 77.7(\mathrm{CH}), 77.9(\mathrm{CH}), 110.7(\mathrm{C}), 120.6(\mathrm{CH})$, 143.7 (C), 172.7 (C); MS m/z (\%) $294\left(\mathrm{M}^{+}, 55\right), 251\left(\mathrm{M}^{+}-\mathrm{CH}_{2} \mathrm{CH}_{2} \mathrm{O}, 64\right), 197$ (58), 179 (37), 151

\footnotetext{
${ }^{a}$ Broadened peaks indicate unresolved coupling. In these cases the higher theoretical multiplicity is consistent with the structural assignment.
} 
(35), 123 (49), 105 (43), 92 (30), 55 (100), 41 (41); HRMS calculated for $\mathrm{C}_{17} \mathrm{H}_{26} \mathrm{O}_{4} \mathrm{M}^{+}$: 294.1831, found 294.1832.

\section{Acknowledgements}

Thanks to Amy Tong for the supply of the organocatalysts and advice on the chiral HPLC analysis. Thanks also to Raisa Imatdieva for obtaining the mass spectra.

\section{References}

1. Trade standard applying to olive oils and olive-pomace oils, International Olive Council, 2006.

2. (a) Bendini, A.; Cerretani, L.; Carrasco-Pancorbo, A.; Gomez-Caravaca, A. M.; SeguraCarretero, A.; Fernandez-Gutierrez, A.; Lercker, G. Molecules 2007, 12, 1679. (b) Franconi, F.; Coinu, R.; Carta, S.; Urgeghe, P. P.; Ieri, F.; Mulinacci, N.; Romani, A. J. Agric. Food. Chem. 2006, 54, 3121. (c) D'Imperio, M.; Dugo, G.; Alfa, M.; Mannina, L.; Segre, A. L. Food Chem. 2007, 102, 956. (d) Waterman, E.; Lockwood, B. Altern. Med. Rev. 2007, 12, 331. (e) Covas, M. I. Pharmacol. Res. 2007, 55, 175. (f) Fini, L.; Hotchkiss, E.; Fogliano, V.; Graziani, G.; Romano, M.; De Vol, E. B.; Qin, H.; Selgrad, M.; Boland, C. R.; Ricciardiello, L. Carcinogenesis 2008, 29, 139. (g) Smith, A. B.; Sperry, J. B.; Han, Q. J. Org. Chem. 2007, 72, 6891.

3. Covas, M. I.; Ruiz-Gutierrez, V.; de la Torre, R.; Kafatos, A.; Lamuela-Raventos, R. M.; Osada, J.; Owen, R. W.; Visioli, F. Nutr. Rev. 2006, 64, S20. (b) Perona, J. S.; CabelloMoruno, R.; Ruiz-Gutierrez, V. J. Nutr. Biochem. 2006, 17, 429.

4. Beauchamp, G. K.; Keast, R. S. J.; Morel, D.; Lin, J. M.; Pika, J.; Han, Q.; Lee, C. H.; Smith, A. B.; Breslin, P. A. S. Nature 2005, 437, 45.

5. Smith, A. B.; Han, Q.; Breslin, P. A. S.; Beauchamp, G. K. Org. Lett. 2005, 7, 5075.

6. (a) Kürti, L.; Czakó, B. In Strategic Applications of Named Reactions in Organic Synthesis: Background and Detailed Mechanisms; Elsevier Academic Press: San Diego, California, United States of America, 2005; p 226-227. (b) Castro, A. M. M. Chem. Rev. 2004, 104, 2939.

7. Brandsma, L.; Vansoolingen, J.; Andringa, H. Synth. Commun. 1990, 20, 2165.

8. (a) Gypser, A.; Michel, D.; Nirschl, D. S.; Sharpless, K. B. J. Org. Chem. 1998, 63, 7322. (b) McCasland, G. E.; Furuta, S.; Johnson, L. F.; Shoolery, J. N. J. Org. Chem. 1963, 28, 894-900. (c) Powell, K. A.; Sable, H. Z.; Hughes, A. L.; Jerauld, J. F.; Katchian, H. Tetrahedron 1972, 28, 2019. (d) Tschamber, T.; Backenstrass, F.; Fritz, H.; Streith, J. Helv. Chim. Acta. 1992, 75, 1052.

9. Vanrheenen, V.; Cha, D. Y.; Hartley, W. M. Org. Synth. 1988, 50-9, 342. 
10. (a) Connelly, S.; Line, K.; Isupov, M. N.; Littlechild, J. A. Org. Biomol. Chem. 2005, 3, 3260. (b) Donohoe, T. J.; Mitchell, L.; Waring, M. J.; Helliwell, M.; Bell, A.; Newcombe, N. J. Org. Biomol. Chem. 2003, 1, 2173.

11. Kohler, B.; Su, T. L.; Chou, T. C.; Jiang, X. J.; Watanabe, K. A. J. Org. Chem. 1993, 58, 1680 .

12. Kurteva, V. B.; Afonso, C. A. M. J. Mol. Catal. A-Chem. 2005, 234, 159.

13. Kurteva, V. B.; Afonso, C. A. M. Tetrahedron 2005, 61, 267.

14. Kueh, J. T. B. Bsc. (Hons), The University of Auckland, 2008.

15. (a) Meyer, M. P.; Del Monte, A. J.; Singleton, D. A. J. Am. Chem. Soc. 1999, 121, 10865.

(b) Yoo, H. Y.; Houk, K. N. J. Am. Chem. Soc. 1994, 116, 12047. (c) Khaledy, M. M.; Kalani, M. Y. S.; Khuong, K. S.; Houk, K. N.; Aviyente, V.; Neier, R.; Soldermann, N.; Velker, J. J. Org. Chem. 2003, 68, 572. (d) Vance, R. L.; Rondan, N. G.; Houk, K. N.; Jensen, F.; Borden, W. T.; Komornicki, A.; Wimmer, E. J. Am. Chem. Soc. 1988, 110, 2314.

16. The 3-D modelling structures were minimised using the semi-empirical AM1 force field method in the ChemBio 3-D Ultra, Version 11 software package.

17. Clayden, J.; Greeves, N.; Warren, S.; Wothers, P. In Organic Chemistry; Oxford University Press Inc.: New York, New York, United States of America, 2001; p 188.

18. Kittel, C.; Kroemer, H. In Thermal Physics; 2nd ed.; W. H. Freeman and Company: San Francisco, California, United States of America, 1980, p 61.

19. Perrin, D. D.; Armarego, W. L. Purification of Laboratory Chemicals; 3rd Ed.; Pergamon Press plc.: Oxford, Great Britain, 1988.

20. Lide, D. R.; Milne, G. W. A. In Handbook of Data on Common Organic Compounds; CRC Press: Boca Raton, Florida, United States of America, 1995; p 830.

21. Maras, A.; Secen, H.; Sutbeyaz, Y.; Balci, M. J. Org. Chem. 1998, 63, 2039.

22. Patwardhan, S.; Dev, S. Synthesis-Stuttgart 1974, 348.

23. Dreef, C. E.; Tuinman, R. J.; Lefeber, A. W. M.; Elle, C. J. J.; Vandermarel, G. A.; Vanboom, J. H. Tetrahedron 1991, 47, 4709.

24. Brunel, Y.; Rousseau, G. J. Org. Chem. 1996, 61, 5793. 